\title{
Biomass and waste as a renewable and sustainable energy source in Vietnam
}

\author{
Nguồn năng lượng tái tạo bền vũng tù sinh khối và rác thải sinh học ở \\ Việt Nam \\ Review paper
}

Schirmer, Matthias*

Ernst-Abbe-Hochschule Jena, Department Industrial Engineering, Carl-Zeiss-Promenade 2, 07745 Jena, Germany

\begin{abstract}
Due to Vietnam's economic development its energy demand will continue to rise by $12-16 \%$ annually over the next few years. The government has realized that supply problems in the energy sector pose a significant threat to further development. Therefore, it is making concerted efforts to modernize the existing energy sector and expand the generating structure. There are ambitious expansion plans in the field of renewable energy sources, too. Owing to its very high potential, biomass could play a key role in energy production. This paper attempts to analyze the current status of biomass based energy production in Vietnam addressing variety of aspects such as biomass potential, legal framework as well as financial aspect. Section 4 contains an overview of ongoing bioenergy projects. Instead of providing a complete picture, these examples are intended to illustrate the various ways in which biomass can be used in different economic sectors. Finally existing barriers as well as action to incentivise bioenergy are discussed.
\end{abstract}

Do phát triển kinh tế, nhu cầu năng luợng của Việt Nam sẽ tiếp tục tăng 12-16\% mỗi năm trong vài năm tới. Chính phủ đã nhận ra rằng vấn đề cung cấp trong lĩnh vưc năng luợng gây ra một mối đe dọa đáng kể cho sụ phát triển tiếp theo. Vì vậy, có các nỗ lực để hiện đại hóa ngành năng luợng hiện có và mở rộng cấu trúc sản sinh năng lương. Cũng có những kế hoạch mở rộng đầy tham vọng trong lĩnh vục nguồn năng luợng tái tạo. Do có tiềm năng rất cao, sinh khối có thể đóng một vai trò quan trọng trong sản xuất năng lương. Bài viết này cố gắng phân tích tình trạng hiện tại của sản xuất năng luọng sinh khối tại Việt Nam giải quyết nhiều khía cạnh nhu tiềm năng sinh khối, khuôn khổ pháp lý cũng nhu các khía cạn về tài chính. Tổng quan về các dư án năng luợng sinh học đang diễn ra được trình bày trong phần 4. Thay vì cung cấp một bức tranh hoàn chỉnh, các ví du được dùng để minh họa cho nhũng cách khác nhau, trong đó sinh khối có thể được sủ dụng trong các lĩnh vục kinh tế khác nhau. Rào cản cuối cùng hiện tại cũng nhu hành động để khuyến khich năng luợng sinh học sẽ được thảo luận.

Keywords: Renewable energy, biomass, biogas, energy generation, waste to energy

\section{Introduction}

Over the past two decades, Vietnam has undergone rapid economic development. Since 1990, its GDP has more than quadrupled, rising from US\$19.89 billion to $\$ 87.53$ billion in 2012 [1]. And its average annual economic growth since 2001 has been 5-8\%. This development has partly been supported by Vietnam's accession to the World Trade Organization (WTO) in 2007 and the associated reduction of trade barriers. This economic success story has been accompanied by significant population growth of about $35 \%$ since 1990 to currently some 90 million.
However, the repercussions of this development include growing environmental problems. Two main challenges are waste management and the sharp rise in energy demand. Apart from hydropower, electricity production is mainly based on the fossil fuels coal and natural gas. To meet increased demand, domestic coal and natural gas production have been greatly expanded in recent years. But in a few years' time, Vietnam's indigenous stocks will run out and it will be forced to import these fuels. Action has been taken to counteract this trend such as capping coal exports and developing renewable energy sources. The government intends to increase the share of 
power generation accounted for by renewables to first $4.5 \%$ by 2020 and $6 \%$ by $2030[2,3]$.

Of the possible renewable energy sources, biomass has a high potential for Vietnam. Although the agricultural sector now only accounts for about $20 \%$ of the country's GDP, in 2012 nearly half the workforce was still employed in farming. Animal waste and crop residue offer great potential for the generation of electricity, which so far has been insufficiently tapped. At the moment, biomass is mainly used by households and small businesses in rural areas and there are currently only a few largescale power plants operating in the megawatt range.

\section{State of the energy sector in Vietnam}

\subsection{Primary energy consumption}

As mentioned above, rapid economic development has also led to a massive rise in energy consumption. An important indicator of this is the increase in primary energy consumption taking into account all energy carriers and sectors in which energy is used (e.g. industry, transport, domestic households). As the following table shows, primary energy consumption has almost doubled in the past decade.

Table 1. Development of energy consumption in Vietnam, 2000-12 (Data based on [1])

\begin{tabular}{ccccc}
\hline Year & $\begin{array}{c}\text { Total primary } \\
\text { energy supply } \\
\text { (TPES) }\end{array}$ & $\begin{array}{c}\text { Electricity } \\
\text { consumption }\end{array}$ & $\begin{array}{c}\text { Electricity consump- } \\
\text { tion/ } \\
\text { population }\end{array}$ & $\begin{array}{c}\text { CO } \mathbf{2}_{\mathbf{2}} \text { emissions/ } \\
\text { population }\end{array}$ \\
\hline [Mtoe] & [TWh] & [MWh/capita] & [t CO $/$ capita] \\
\hline 2000 & 28.7 & 22.9 & 0.30 & 0.57 \\
2002 & 33.4 & 30.8 & 0.39 & 0.72 \\
2006 & 39.0 & 40.2 & 0.49 & 0.90 \\
2008 & 42.5 & 54.6 & 0.66 & 0.99 \\
\hline
\end{tabular}

In 2012, the primary energy carriers were subdivided as follows:

$\begin{array}{ll}\text { Oil: } & 34 \% \\ \text { Coal/peat: } & 26 \% \\ \text { Biomass: } & 24 \% \\ \text { Natural gas: } & 12 \% \\ \text { Hydro: } & 4 \%\end{array}$

As can be seen, about a third of Vietnam's primary energy consumption is oil-based. Although Vietnam has developed into a major oil exporter in the Asia-Pacific region in recent years, petroleum products are still largely imported due to the country's low refining capacity. In fact, Vietnam imports about 2.5 million barrels of petrol a month - the second-highest amount of any Asian country [4].

Domestic coal production is currently still sufficient to meet demand by industry and power plants. But since a number of new coal-fired power plants will go into operation in 2015, Vietnam could in future become dependent on coal imports.
Biomass's current contribution to primary energy consumption boils down to its traditional use in rural areas, including for cooking and heating.

\subsection{Electricity market}

As can be seen from Table 1, energy usage is climbing even faster than primary energy consumption. Electricity consumption has risen more than fivefold, from about 22 TWh in 2000 to $113 \mathrm{TWh}$ in 2012 [1]. Over the past decade, consumption has increased by about $15 \%$ per annum, and annual rises are expected to remain in the range of $12-16 \%$ in the years to come. The reasons for this are ongoing industrialization and in particular rising demand among domestic households.

The following graph shows the development of electricity generation since 1990 by energy carriers. 


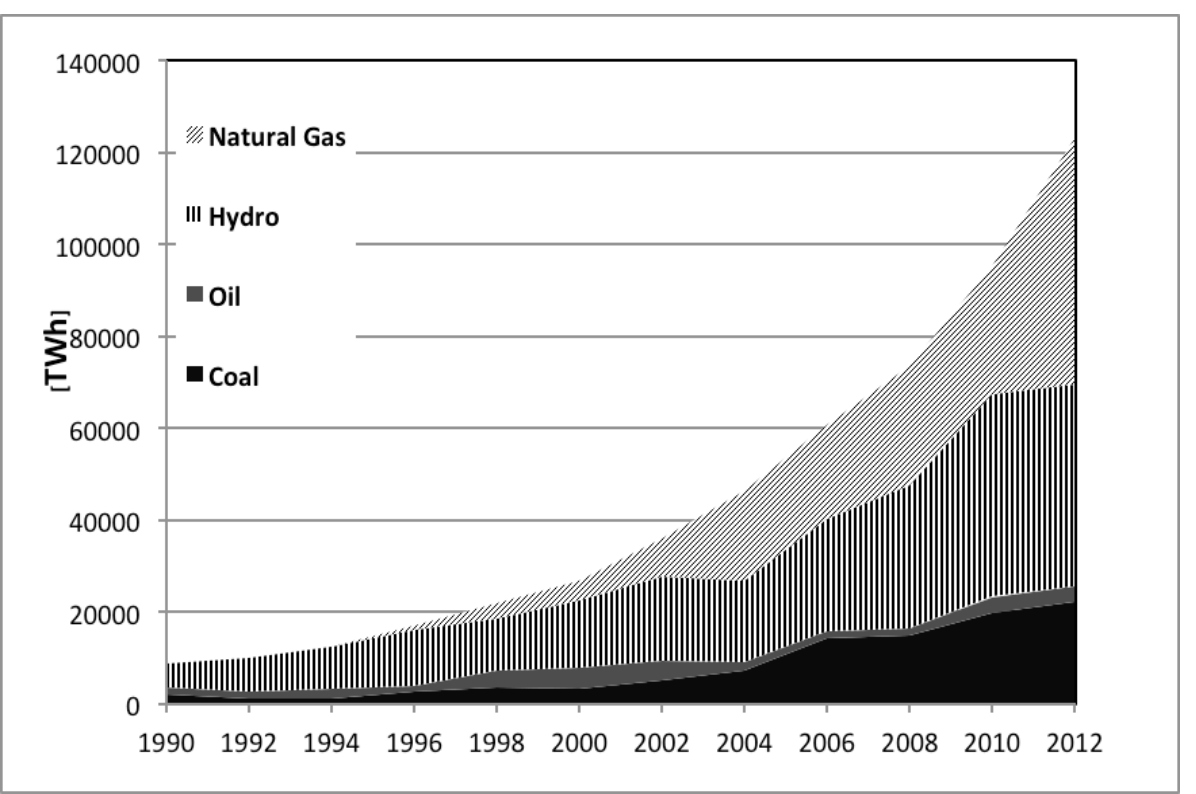

Figure 1. Development of electricity generation, 1990-2012 (Data based on [1])

In 2012 , approximately $43 \%$ of the total electricity generated in Vietnam came from gas-fired power plants. Natural gas has hence replaced hydropower as the main source of energy in power generation. Even so, about $30 \%$ of electricity is currently still generated by hydroelectric plants. Because hydropower depends strongly on the weather and seasonal influences and is hence subject to fluctuation, the aims are to reduce the share of hydroelectric power in the energy mix in the medium to long term and to diminish fluctuation by means of pumped storage plants. After natural gas and hydropower, coal-fired power plants are the third pillar of power generation, accounting for nearly $20 \%$.

Even though generating capacity has been substantially increased in recent years, power production is still lagging behind increasing demand. As a result, power cuts and rationing are not unusual, chiefly in rural areas but also to some extent in cities and industrial parks. To improve the situation, the government is planning bold action to enlarge generating capacity from currently $25 \mathrm{GW}$ to 75 GW by 2020 and $146.8 \mathrm{GW}$ by 2030 [3]. These plans include the development of 95 new power plants over the next ten years.

This capacity surge is to be accompanied by a change in the energy mix. With the share of hydropower being reduced, coal is set to play a far bigger role over the next few years. Moreover, Vietnam also plans to move into nuclear energy, with building work on its first nuclear power plant scheduled for 2017. The share of renewables (excluding hydropower) in the electricity mix is planned to increase to $4.5 \%$ by 2020 [3]. The following section sets out the potential for bioenergy sources.

\section{Potential of biomass and waste in Vietnam}

As shown in Section 2, energy demand in Vietnam is steadily rising. In addition to fossil fuels, the government is keen to boost the use of renewables. Biomass has great potential owing to the country's strong agricultural sector and its climatic conditions.

However, precisely assessing the quantities of biomass available for energy use isn't easy. Some published sources of data fail to indicate how the figures were compiled or to include clear definitions of different types of biomass. For example, it isn't always apparent whether a distinction is drawn between the theoretical total potential and the technically usable potential. In addition, because some types of biomass can be used in different ways (e.g. wood residue can also be recycled in the woodworking or paper industry), different studies sometimes arrive at very different findings.

The various sources of biomass suitable for energy generation energy are shown in Figure 2.

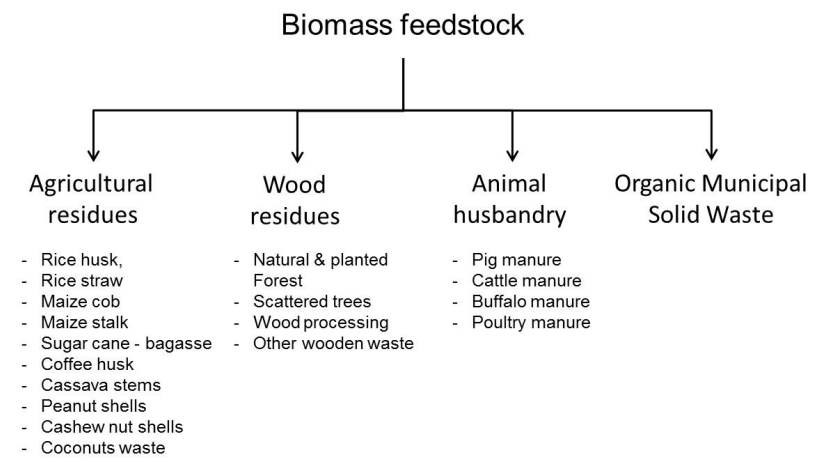

Figure 2. Potential sources of biomass for power generation

\subsection{Agricultural residue}

Agricultural residue is the most important source of biomass in Vietnam. It accrues either as crop residue directly in the fields or afterwards during the processing of agricultural products. The crop residue ratio (CRR) indicates the proportion of residue within a certain quantity of crop and can be used to estimate the amount of residue remain- 
ing. However, note that the CRR can only be used to calculate the theoretical biomass potential [5].

Rice is Vietnam's foremost agricultural production and export commodity. About $50 \%$ of production is concentrated in the Mekong Delta with another 20\% in the Red River Delta. Following production increases in recent years, nearly 44 million tonnes of rice was produced in the country in 2012 [6]. Rice production also results in huge amounts of rice straw and rice husk. Rice straw often remains on farms as animal feed or is burned directly on the fields or dug into the soil. The rice husk accruing during the processing of rice grains is partly used as fuel for cooking stoves, as fertilizer, or as aggregate in cement and brick production. In recent years, it has also been compressed into briquettes and sold as fuel. The figures for the amount of rice straw available vary between 17 and 50 million $\mathrm{t} / \mathrm{a}$ for rice straw and 2-8 million t/a for rice husk [7], [8], [9].

Sugarcane is another important agricultural product. During the harvest, about $40 \%$ of the crop (tips and leaves) accumulates as residue and is mostly left unused in the fields. During sugar production, another $15-35 \%$ of the crop is left as bagasse. Bagasse is mainly incinerated to generate energy in the sugar industry, although smaller quantities are used as animal feed.

Due to the increased demand for animal feed, maize cultivation has more than doubled in the past decade. The residue comprising the stems and empty corn cobs is sometimes used as animal feed or cooking fuel. About 1 million t/a empty corn cobs and another 9 million $\mathrm{t} / \mathrm{a}$ of stems are assumed to accrue.

After rice, coffee is Vietnam's second-most important agricultural export. The varieties grown are Robusta in the central highlands (93\% of the total) and Arabica in the north (the remaining 7\%) [8]. In 2012, coffee production reached approximately 1.1 million tonnes. The residue comprised 130,000-170,000 tonnes of coffee pods.

Cassava production has developed very dynamically in recent years. Mainly processed into starch, the annual harvest is almost 10 million tonnes. Production involves solid residue in the order of 2.5-3 million t/a cassava stems. In addition, large amounts of liquid waste are created which are suitable for biogas production.

The production and residue quantities of the main agricultural products are shown in Table 2:

Table 2. Overview of production and residue quantities of Vietnam's main crops

\begin{tabular}{lrlr}
\hline & Production (2012) & Residue & {$[$ Mio t] } \\
\hline Rice & [Mio t] & & $17.0-50.0$ \\
& 43.74 & Rice straw & $2.0-8.0$ \\
Sugarcane & & Rice husk & 7.6 \\
& 19.02 & Leaves, top & $2.4-7.8$ \\
Maize & & Bagasse & 1.0 \\
& 4.97 & Maize cobs & 9.0 \\
Coffee & & Maize stalks & $0.1-0.2$ \\
Cassava & 1.10 & Coffee bean shells & $2.5-3.0$ \\
Peanuts & 9.45 & Cassava stems & 0.2 \\
\hline Total & 0.47 & Peanut shells & $\mathbf{4 1 . 8}-\mathbf{8 6 . 8}$ \\
\hline
\end{tabular}

\subsection{Wood residue}

Vietnam has about 13 million hectares of forestland: 10 million hectares of natural forest and 3 million hectares of plantations. To determine the theoretical yield of wood in natural forests and forest plantations, the following sustainable impact rates are assumed [7]:

\section{Natural forest: $\quad 1.0 \mathrm{t} / \mathrm{ha} / \mathrm{a}$ \\ Forest plantation: $2.5 \mathrm{t} / \mathrm{ha} / \mathrm{a}$}

This results in an annual wood yield of approximately 17.5 million tonnes. In 2010 , about 5 million $\mathrm{m}^{3}$ of domestic wood was processed in the wood-processing industry, $90 \%$ of which came from plantations. Even so, the majority of the total wood used $(>70 \%)$ is imported. During processing, waste accrues in the form of wood chips, bark and sawdust. The following table summarizes the theoretical total amounts of wood and wood waste.
Table 3. Amounts of wood and wood waste (in million t/a) [7], [8]

\begin{tabular}{lr} 
Natural forest & $6.8-10.3$ \\
Forest plantation & $3.8-9.7$ \\
Scattered trees & $0.5-7.8$ \\
Wood processing industry & $4.0-6.7$ \\
Waste wood & 0.8 \\
\hline Total & $\mathbf{1 5 . 1}-\mathbf{3 5 . 3}$
\end{tabular}

\subsection{Animal residues}

Animal husbandry - especially pig, poultry and water buffalo farming - is a very important economic sector for Vietnam. Rated by the number of animals, Vietnam has the world's second-biggest duck-farming sector and is also the fourth-biggest pig farming country. The structure of animal husbandry is still dominated by micro and small farmers with just a few animals (5-20). However, this may change in the next few years since the fastest growth is currently enjoyed by cattle facilities with intensive farming. 
Then again, these huge stocks of animals also affect the environment in various ways, the main problem being waste in the form of excrement and liquid manure. In Table 4, the annual quantities of animal excrement in 2012 are estimated. The majority of this waste currently goes unused and poses a significant disposal problem.
This is a shame, for apart from usage as fertilizer, this waste is particularly suitable for generating biogas. This is a technology that has been applied in Vietnam since the 1960 s, and small biogas plants are in operation on tens of thousands of farms. The resulting biogas is used mainly for cooking and lighting. On the other hand, large-scale biogas CHP (combined heat and power) plants are rare.

Table 4: Solid waste from animal husbandry (according to [5], [6] and [10])

\begin{tabular}{lccc} 
Animals & $\begin{array}{c}\text { Total head } \\
(\mathbf{2 0 1 2})\end{array}$ & $\begin{array}{c}\text { Daily discharged } \\
\text { waste amount }\end{array}$ & Total \\
\hline Pigs & {$[$ million] } & {$[\mathrm{kg} /$ head/day] } & {$[$ million t/a] } \\
Cattle & 26.5 & $1.2-4.0$ & $11.6-38.7$ \\
Buffalo & 5.2 & $15-20$ & $28.4-37.9$ \\
Poultry & 2.6 & $18-25$ & $17.3-24.0$ \\
Total & 308.5 & $0.18-0.34$ & $20.3-38.3$ \\
\hline & & & $\mathbf{7 7 . 6}-\mathbf{1 3 8 . 9}$
\end{tabular}

\subsection{Organic municipal solid waste}

In recent years, Vietnam's growing economic strength and prosperity have led to sharp increases in the amount of refuse generated - not just industrial but also municipal waste. Not surprisingly, the conurbations are responsible for the highest increases in the quantities of waste. The specific amounts are between 0.7 and $1.3 \mathrm{~kg} / \mathrm{head} /$ day [11], about $70-80 \%$ of which is collected and sorted . In agricultural areas, both the specific amount of waste and the collection and sorting rate are much lower, probably in the order of $20-45 \%$. Depending on the settlement structure and season, the levels of organic components in solid municipal waste vary substantially between 55 and $90 \%$.

A precise assessment of the amount of municipal waste generated annually is very difficult. Some of the published data are outdated and it is often uncertain what types of waste have been categorized as municipal waste in the statistics. Nonetheless, about 15 million tonnes of municipal solid waste can be assumed to have been generated in 2009.

Most municipal solid waste is currently landfilled. There are hundreds of landfills in Vietnam, and their facilities vary greatly. Some already have leachate and gas capture systems; others are far simpler composting plants, and it is doubtful whether this type of disposal is economically or ecologically suitable for municipal waste. In addition, there are also a few small waste incinerators, although their emissions scrubbing systems are inadequate. The first large industrial-scale plant with a capacity of $75 \mathrm{t}$ /day is currently being built near Hanoi [12].

\section{Current use of biomass and waste to generate energy}

\subsection{Legal framework and incentives}

A safe, stable power supply is essential for Vietnam's further development, but will require tremendous efforts in order to be achieved. To this end, a national master plan for the development of the country's power sector (Decision 1208/QD-TTg) was approved on 21 July 2011 [3]. A key target is the electricity mix planned for 2020 , in which renewables are to make up $4.5 \%$. The biomass generating capacity is to be raised to $500 \mathrm{MW}$ by 2020 and then 2,000 MW by 2030. In addition, investment is to be carried out in order to improve data collection and applied research in this field.

Furthermore, financial incentives have been approved to boost the generation of electricity from biomass and waste. Following the introduction of a feed-in tariff for wind energy back in 2011, Decision No. 24/2014/QDTTg regulating the future planning and development of energy from biomass, grid access, and purchase agreements between energy producers and the network operator came into force on 10 May 2014 [13]. It provides for a feed-in tariff for electricity generated from solid biomass of 1,220 VND (5.8 US cents) per kWh (excluding value added tax), as long as power is produced using CHP. For all other types of plants, the tariff is set annually by the Vietnamese Ministry of Industry and Trade (MOIT). The feed-in tariff is calculated based on the avoided cost of producing $1 \mathrm{kWh}$ electricity from imported coal. In addition, project developers can apply for loans from international financial institutions such as the World Bank, the Asia Development Bank and the KfW ('Kreditanstalt für Wiederaufbau' - the German reconstruction bank). Feedin tariffs are also laid down for power generation from the incineration of solid waste in Decision No. 31/2014/QDTTg, which came into force on 20 June 2014 [14]. The feed-in tariff is 2,114 VND (10.05 cents) per kWh for waste incinerated directly, and 1,532 VND (7.28 Cents) per $\mathrm{kWh}$ for generation from landfill gas.

In addition to these guaranteed revenue streams, there are a number of other benefits such as reduced corporation tax, higher depreciation allowances for plant and machinery, and reduced land lease rates and environmental protection fees. 


\subsection{Current projects}

This section contains an overview of the large-scale bioenergy projects that have been implemented. Instead of providing a complete picture (which would be difficult in this dynamic market), these examples are intended to illustrate the various ways in which biomass can be used in different economic sectors.

\subsubsection{Use of bagasse for CHP in sugar mills}

In Section 3, we saw that bagasse makes up about 15$35 \%$ of total crop weight in sugar production. Bagasse is a fibrous material with high cellulose content. Depending on its water content, the calorific value of bagasse ranges between $7.6 \mathrm{MJ} / \mathrm{kg}$ (water content: $50 \%$ ) and $12 \mathrm{MJ} / \mathrm{kg}$ (water content: 10\%). This residue is hence ideal for incineration directly in the sugar mill, even though as recently as the 1990s bagasse was still regarded as an undesirable waste material in sugar production.

The sugar industry in Vietnam consists of 40 sugar mills with a capacity of 139,800 TCD (tonnes of cane per day). All the mills use bagasse for combined process steam and power production, saving considerable amounts of fossil fuel. As the sugar mills are mostly in rural areas, local power generation also means that transmission costs and losses can be slashed compared to drawing power from the national grid. Another advantage is that sugar processing (and hence the use of bagasse) takes placed during the dry season. This helps mitigate the electricity shortages occurring during this period owing to reduced hydropower capacity.

The total electrical capacity of these sugar mill power plants is $150 \mathrm{MW}$. However, only six sugar mills with a maximum capacity of $88.5 \mathrm{MW}$ feed power into the grid. The plants vary in size between 1 and $25 \mathrm{MW}_{\mathrm{e}}$. About half of the mills plan to increase their capacity in the next few years by fitting new boilers and turbines. [15] Since the efficiency of the existing systems is rather poor due to their low steam pressure $(<40$ bar $)$ and the use of backpressure turbines, there is plenty of scope for optimization.

\subsubsection{Use of rice husk in biomass power plants}

Despite biomass's huge potential, according to [5] there is currently just one large-scale power plant outside the sugar industry which is fuelled by solid biomass - in this case rice husk.

A number of sources report that planning for another rice husk-fired power station in Hau Giang province began in December 2013. The necessary capital investment has been budgeted at roughly $\$ 31$ million. Every day, the plant will require 150 tonnes of rice husk and deliver 10 MW of electricity. No details of the planned combustion technology or steam parameters are available. Due to the high ash content of rice husk (16-18\%), recycling options for the combustion residue always need to be considered. In this case, the residue is to be used as aggregate in the cement industry.
According to MOIT, over the next five years another 20 plants of this type are to be built by a Malaysian consortium. The main power plant components are to be supplied by Torftech Ltd and ERK EckRohrkessel GmbH. Five plants are to be built in the Mekong Delta in the provinces of An Giang, Kien Giang, Hau Giang, Dong Thap and Can Tho . A shortage of rice husk is not expected since the total daily intake of 1,250 tonnes is dwarfed by the average production in the Mekong Delta of 13,700 t/d. The feed-in tariffs for electricity from biomass in force since May 2014 provide an important incentive for this major investment.

Other planned investments in the order of 6-10 MW are listed in [17]. The technology favoured for these systems is fluidized bed combustion.

\subsubsection{Use of biomass to generate heat in agriculture}

Large amounts of heat are required for drying when rice, coconut, coffee, cashew and wood are processed. Some of this heat (especially in the wood-processing industry) is supplied through the use of wood residue. Combustion usually takes place in a rotary kiln with the subsequent generation of hot steam at a rate of 5-10 t/h. An identical method is employed in the coconut processing industry, the main fuels used being rice husk and coconut shells.

Outside farming, large amounts of rice husk are used when firing bricks. This is especially widespread in the Mekong Delta, where significant quantities of rice husk accrue and the price of coal is higher than elsewhere owing to the mines being so far away.

\subsubsection{Biogas}

When describing the use of biogas in Vietnam, a distinction must be drawn between small systems in rural households and the commercial operation of medium-sized and large plants.

Thanks to several biogas programmes, the number of biogas systems in rural areas has increased dramatically over the past ten years. Some authors quote a figure of more than 200,000 small-scale systems while the SNV assumes that there are approximately 500,000 small-scale plants in operation [8]. They mostly have a round, brick digester with a volume of between 5 and $20 \mathrm{~m}^{3}$. The biogas arising is used mainly for cooking while the sludge is applied as fertilizer. The most common form of substrate used is waste from animal husbandry.

By contrast, there are only a handful of large-scale industrially operated biogas plants. According to [17] there are merely a few large plants used to generate electricity with a capacity ranging from $150 \mathrm{~kW}$ to $3.5 \mathrm{MW}$. Other plants with capacities of 1.2-3.5 MW are currently being planned [18]. The substrates used are animal waste, residues from cassava and fish processing, and household waste. In addition, there are several plants in which biogas is used to generate steam at a rate of $5-12 \mathrm{t} / \mathrm{h}$. 
The number of medium-sized and large plants is expected to rise in the next few years. This development will be buoyed by increasing centralization and industrialization in meat and milk production as well as rising pressure to dispose of municipal waste owing to limited landfill space. Moreover, biogas plants are likely to be stimulated by the prospect of a feed-in tariff for electricity from biogas being introduced in 2014 or 2015 at the latest.

\section{Future prospects of biomass energy use}

\subsection{Existing barriers to biomass energy use}

As shown in Section 4, although there are a number of hopeful projects boosting the production of energy from biomass, limited use is made of the existing potential. The various reasons for this are discussed below.

\subsubsection{Supply of biomass}

The majority of agricultural waste in Vietnam occurs locally. One example is the huge volume of rice husk, whose processing structure means that it arises in many small rice mills. The same is true of residue from maize processing and also municipal waste in rural areas. Since the success of biomass energy projects hinges on a reliable supply of biomass, efficient collection, transportation and storage systems need to be set up. Supply reliability has to be ensured for a period of over twenty years. The parameters which need to be taken into account are the biomass's quality, quantity and price. However, the data required in order to set up efficient supply chains - such as information on the regional distribution of the biomass potential in individual provinces and seasonal fluctuations - are normally non-existent [19].

\subsubsection{Economic environment}

One of the biggest obstacles to the further expansion of renewable energies is the fact that producing electricity in this way is normally more expensive than conventional power generation. One reason for this is the relatively high investment costs for new technologies in connection with limited access to risk capital. Consequently, the resulting payback periods of these projects are frequently 20-30 years, if not longer.

This situation is exacerbated by government subsidies for coal-based power production and the resulting low electricity prices. The price of electricity therefore needs to be raised and price calculation clearly regulated since the current prices by no means reflect the actual economic or environmental costs.

Although the feed-in tariffs for electricity generated by CHP biomass power plants and waste-fired power stations are an important step forward, by themselves they're not enough to incentivise investment. For example, there are no rules in place concerning how feed-in tariffs are to be revised and adapted. In addition, the feed-in tariff for electricity from CHP plants is not very attractive. The feed-in tariff for bioenergy plants based on avoided costs is $4.5-5$ US cents $/ \mathrm{kWh}$, which is still too low to prompt the necessary investment. Yet according to [10], as little as 6 cents/kWh would be enough to accelerate the grid connection of bioenergy plants.

\subsubsection{Legal framework}

Another barrier is the unclear legislation or even lack of legal regulations. Nonetheless, some progress has been made in this area this year, including for instance a guaranteed purchase commitment by Vietnam Electricity (EVN) for electricity from grid-connected biomass power plants over a period of 20 years.

\subsubsection{Lack of expertise}

Apart from the above-mentioned obstacles, the bioenergy sector is also suffering from inadequate data and a lack of information. This applies in different ways to legal, economic and technical aspects, and makes investment decisions far riskier.

Due to the low number of industrial-scale projects carried out, there is often a lack of experience among stakeholders such as government agencies, biomass suppliers, technology and equipment suppliers, investors and operators. From investors' viewpoint, the lack of qualified personnel in government agencies is a problem, leading not only to project delays but also misunderstandings and in the worst-case project failure.

\subsection{Action to incentivise bioenergy projects}

The goals for the further expansion of renewable energies are laid down in the "Vietnam National Energy Development Strategy to 2020, with a Vision to 2050'. If renewables really are to account for $4.5 \%$ of the electricity mix by 2020 , above all additional decisions must be taken by the government in order to improve the investment climate.

Some fiscal measures have already been taken in recent years such as exemption from import duties on imported items used as capital assets and reduced corporation tax. Nevertheless, many bioenergy projects are still not economically viable as things stand. The extraction of fossil fuels (especially coal) means that electricity prices are currently below market levels, making it difficult for bioenergy plants to compete. One action which is urgently necessary is therefore to raise electricity prices. Moreover, regulations must be introduced regarding the revision and adaptation of the feed-in tariffs now in force and also their extension to include biogas plants.

From an investor's point of view, apart from an improved economic framework and financing options, above all the legal regulations and responsibilities need to be simplified. The existing bureaucratic hurdles are a serious obstacle to market entry, especially for foreign project developers. Approval procedures need to be significantly simplified and the responsibilities of different authorities combined. 
Due to the lack of both experience and human resources in bioenergy, another important element is to encourage training in this field among all sorts of stakeholders. For example, training courses need to be introduced to improve the knowledge of government personnel concerning current legal regulations and how approval procedures are to be carried out. Moreover, trained workers are required for the safe, efficient operation of power plants, especially in the areas of maintenance, repair, and health and safety. In addition, relevant training as well as research and development need to be massively increased in higher education. Research is required in for example the following areas:

- The collection of data on appropriate biomass locations taking into account biomass accumulation at a provincial and local level

- The development of suitable biomass collection and transport systems

- The development of efficient processing methods to improve transport and storage properties

- The optimization of existing technologies in terms of fuel variability and partial load behaviour

Much more government funding is required for research projects of this nature. Furthermore, existing international cooperation needs to be expanded and intensified.

\section{Summary}

Due to Vietnam's economic development, according to a number of different projections its energy demand will continue to rise by $12-16 \%$ annually over the next few years. The government has realized that supply problems in the energy sector pose a significant threat to further development. Therefore, it is making concerted efforts to modernize the existing energy sector and expand the generating structure. Although a crash programme for the construction of new power plants is set to raise capacity from $25 \mathrm{GW}$ to $75 \mathrm{GW}$ by 2020 , it is mainly based on fossil fuels such as coal and nuclear power.

Even so, there are also ambitious expansion plans in the field of renewable energy sources. Owing to its very high potential, biomass could play a key role in energy production. This has been recognized by the government, which in recent years has adopted a series of regulations and incentives to improve the investment climate for biomass. The feed-in tariffs which came into force this year are an important step forward. As a result, potential for growth is now emerging in particular regarding the use of bagasse, rice husk and municipal waste, and some promising projects for the generation of electricity from rice husk are currently in the planning stage.

There is also considerable potential regarding power generation using biogas. It is hoped that the promised feed-in tariffs are quickly adopted and become a major incentive for investors.

If the existing barriers can be successfully reduced, too, energy production from biomass could reduce Vietnam's dependence on energy imports and make a lasting contribution to the country's further development.

\section{References}

[1] International Energy Agency IEA (2014): Country report Vietnam. http://www.iea.org/statistics/ statisticssearch/report

[2] The Prime Minister (2007): Decision No. 1855/QĐTTg of "Vietnam National Energy Development Strategy to 2020, with a Vision to 2050". Hanoi, Vietnam.

[3] The Prime Minister (2011): Decision No. 1208/QDTTg Approve the National Master Plan for power development for the $2011-2020$ period with the vision to 2030. Hanoi, Vietnam.

[4] U.S. Energy Information Administration EIA (2013): Country Analysis Vietnam 2012. http://www.iberglobal.com/files/vietnam_eia.pdf.

[5] Wittmaier, M., Bilitewski B., et al. (2005): Handbook - Decision Support System (DSS) for the application of RENEWABLE ENERGY from Biogas and Biomass Combustion under particular consideration of framework conditions in VIETNAM and THAILAND. Bremen, Germany.

[6] General statistics office of Vietnam (2014): Statistical data on agriculture, forestry and fishery. www.gso.gov.vn.

[7] Nguyen Duc Cuong et al. (2011): Identification of biomass market opportunities in Vietnam. Deutsche Gesellschaft für Internationale Zusammenarbeit (GIZ) GmbH, Berlin, Germany.

[8] Zwebe, D. et al.(2012): Biomass Business Opportunities Viet Nam. SNV - Netherland Development Organisation Vietnam. Hanoi, Vietnam.

[9] Nguyen Tien Long (2013): Report on the status of bioenergy development in Vietnam; Ministry of agriculture and rural development of Vietnam. in http://www.iea.org/media/technologyplatform/works hops/southeastasiabioenergy2014/Vietnam.pdf.

[10] Mosquera, J. et al. (2012): Manure management options and opportunities. Wangeningen University. Presentation at Global Research Alliance workshop. Bangkok, Thailand. 14 -15 March 2012.

[11] Thanh, N.P., Matsui, Y. (2011): Municipal Solid Waste Management in Vietnam: Status and the Strategic Actions. International Journal on Environmental Research, 5(2): 285-296. ISSN: 1735-6865.

[12] Nguyen Hoai Duc (2014): Waste Management in Vietnam - Potential for power generation. Presentation at GIZ Workshop, HCMC, 21 May 2014.

[13] The Prime Minister (2014a): Decision No. 24/2014/QD-TTg date March 24, 2014 on the support mechanism for the development of biomass power projects in Vietnam.

[14] The Prime Minister (2014b): Decision No. 
31/2014/QD-TTg date May 5, 2014 on the support mechanism for the development of solid waste power projects in Vietnam.

[15] Nguyen Van Loc (2014): Potential of residue from sugar production for the generation of Heat and Power in Vietnam; Presentation at GIZ-PEPWorkshop. Berlin, Germany. 3. June 2014.

[16] Nguyen Duc Cuong (2014): Energy from Biomass and Biogas in Vietnam. Presentation at GIZWorkshop. Berlin, Germany. 27.June 2014.

[17] Nguyen Dang Anh Thi (2014): Bio-Energy in Vi- etnam - Opportunities and Challenges. Presentation at Indochina Capital Workshop. 4 June 2014.

[18] Voss, K., Kossmann, W. (2012): Chancen am Mekong. Biogas-Journal. 4_2012.

[19] Leinonen, A.; Nguyen D. C. (2013): Development of biomass fuel chains in Vietnam; VTT Technology 134; Espoo, Finland.

[20] Le Thi Hai Duong et al. (2014): Bioenergie Vietnam 2014 - Zielmarktanalyse mit Profilen der Marktakteure. Deutsche Gesellschaft für Internationale Zusammenarbeit (GIZ) GmbH. Berlin, Germany. 